\title{
Photosynthetic carbon metabolism and biochemical composition of spring phytoplankton assemblages enclosed in microcosms: the diatom - Phaeocystis sp. succession
}

\author{
Emilio Fernández ${ }^{1,2}$, Pablo Serret ${ }^{2}$, Iosu de Madariaga ${ }^{3}$, Derek S. Harbour ${ }^{1}$, \\ Anthony G. Davies ${ }^{1}$ \\ 1 Plymouth Marine Laboratory, Prospect Place, West Hoe, Plymouth PL1 3DH, United Kingdom \\ ${ }^{2}$ Departamento de Biología de Organismos y Sistemas, Unidad de Ecología, Universidad de Oviedo, E-33005 Oviedo, Spain \\ ${ }^{3}$ Departamento de Biología Vegetal y Ecología, Laboratorio de Ecología, Universidad del Pais Vasco, PO Box 644, \\ E-48080 Bilbao, Spain
}

\begin{abstract}
Samples of natural phytoplankton assemblages were taken on 4 occasions between 28 March and 19 April 1990 at 2 stations located to the southwest of Plymouth (UK) and incubated in experimental microcosms under constant light and temperature. ${ }^{14} \mathrm{C}$ incorporation into cell constituents [proteins, polysaccharides, lipids and low molecular weight metabolites (LMWM)] and the biochemical composition of the phytoplankton were monitored during the experiments. Different phytoplankton populations developed in the microcosms. Microflagellates which dominated in the first experiments were followed in later experiments by a multispecific bloom of chain-forming diatoms, and these in turn by a bloom of Phaeocystis sp. Each assemblage was characterized by a different metabolic behaviour High ${ }^{14} \mathrm{C}$ incorporation into LMWM and lipids was observed during non-growth periods when microflagellates dominated. High ${ }^{14} \mathrm{C}$ incorporation into proteins and relatively high specific rates of protein synthesis $\left(0.45 \pm 0.1 \mathrm{~d}^{-1}\right)$ were measured during the late growth phase of the diatom bloom. Synthesis of acid-soluble carbohydrates (ASC) also occurred in this period. As Phaeocystis $5 \mathrm{p}$. increased, ${ }^{14} \mathrm{C}$ incorporation into LMWM and polysaccharides showed a significant rise. These metabolic patterns were consistent with earlier models of the development of Phaeocystis sp. blooms. Polysaccharidecarbon concentration, both acid-soluble and acid-insoluble, showed dramatic increases during the early stages of the bloom. Enhanced polysaccharide synthesis was related to the formation of the mucilaginous colonial matrix and is suggested to be a physiological strategy tending to increase colony buoyancy. During the decline of the Phaeocystis sp. bloom, the proportion of ${ }^{14} \mathrm{C}$ incorporated into LMWM decreased, possibly as a result of disruption of the colonies, whereas incorporation into lipids exhibited a consistent increase. The accumulation of high-energy storage products is interpreted as a metabolic adaptation for overwintering under very low light levels. As a consequence of the distinct metabolic patterns of each successional stage, the protein- $\mathrm{C} / \mathrm{acid}$-insoluble polysaccharide- $\mathrm{C}$ ratio showed a marked decrease, whereas the relative contribution of ASC-C to the total measured carbon displayed a significant increase. In addition, carbon incorporation into LMWM also showed a slight but continuous increase. It is suggested that the metabolic changes associated with the diatom - Phaeocystis sp. succession are in accord with a marked shift in the trophic structure of the planktonic ecosystem from the classical food chain in the earlier stages, and mainly during the diatom bloom, to a preponderance of the microbial loop at the end of the Phaeocystis sp. bloom.
\end{abstract}

\section{INTRODUCTION}

Phytoplankton cells have the capacity to rapidly adjust their photosynthetic metabolism in response to changes in their physico-chemical environment. Their physiological adaptation involves a complex series of interacting processes, occurring on different time scales which ultimately define the physiological state and, consequently, the growth rate of a given population. Knowledge of these processes is central to the 
understanding of the physiological strategies adopted by phytoplankton and how these influence species succession.

One of the frequently employed approaches dealing with this topic is to study the patterns of synthesis of organic polymers through examining ${ }^{14} \mathrm{C}$ labelling of the primary cellular biochemical pools (i.e. proteins, carbohydrates and lipids) (see review in Morris 1981). The main interest of this approach lies, firstly, in the recognized strong correlation between protein synthesis and population growth rate as revealed in culture work and field studies of both freshwater and marine systems (Morris et al. 1974, Lancelot et al. 1986, Lean et al. 1989), and, secondly, in the close relationship frequently found between photosynthate partitioning and phytoplankton physiological state (Morris 1981, Barlow 1984, Hama \& Honjo 1987). Furthermore, the relative rates of synthesis of the major cellular biomolecules will partially determine the chemical composition of the population.

Extensive culture work has been carried out to clarify the influence that diverse environmental factors such as tomperature, irradiance, the spectral quality of the light and inorganic nutrient concentration exert upon the flows of newly incorporated photosynthetic carbon in isolated phytoplankton species (e.g. Morris et al. 1974, Konopka 1983, Harding et al. 1985, Rivkin 1989). Most of these studies employed the solvent extraction protocol described by Li et al. (1980). In spite of the methodological limitations reported for this method (McConville et al. 1985, Hama et al. 1988b), some general patterns at the cellular level have emerged; most of the results obtained in these investigations cannot, however, be extrapolated easily to natural conditions.

Changes in carbon metabolism observed in multispecific natural phytoplankton assemblages in response to the environment reflect a combination of within-species physiological adaptations superimposed upon changes in species composition. Given that both processes, although occurring simultaneously, operate on different time scales, and because interspecific differences in photosynthetic carbon incorporation have been shown to be significant (Rivkin 1985, Madariaga 1992), the determination and interpretation of phytoplankton physiological state at the community level are extremely difficult

The sampling and experimental design undertaken in this study represent attempts to overcome some of these problems by examining the changes in physiological state and the subsequent modifications in biochemical composition of natural phytoplankton populations on 2 different time scales. Firstly, short-term variations within a population were determined by monitoring the labelling patterns of assimilated carbon in natural assemblages contained in experimental microcosms at $12 \mathrm{~h}$ intervals. Secondly, mesoscale metabolic changes at the community level were examined in this work by repeating the same experimental procedure throughout early spring During this period, phytoplankton assemblages in temperate coastal areas undergo major changes in species composition from chain-forming diatoms to the colonial prymnesiophyte Phaeocystis sp. (Holligan \& Harbour 1977, Lancelot \& Mathot 1987). As far as we are aware, there are no published data linking daily patterns of photosynthetic carbon metabolism to the resulting biochemical composition, at both population and successional levels, during the highly variable mixed-stratified transition period in temperate seas

The experimental study ran in parallel with a spring bloom field survey (Davies et al. 1992), in order to determine the changes in carbon flows into photosynthctic ond-products and biochemical composition associated with the growth and decline phases of the phytoplankton during the diatom - Phaeocystis sp. succession.

\section{METHODS}

Water samples for the experiments were taken from $10 \mathrm{~m}$ depth during weekly visits to Stns $\mathrm{L} 4\left(50^{\circ} 15^{\prime} \mathrm{N}\right.$, $4^{\circ} 13^{\prime} \mathrm{W}_{i}$ depth $\left.51 \mathrm{~m}\right)$ and $\mathrm{E} 1\left(50^{\circ} 07^{\prime} \mathrm{N}, 4^{\circ} 22^{\prime} \mathrm{W}\right.$; depth $72 \mathrm{~m}$ ), located to the southwest of Plymouth (UK). Sampling was conducted on 4 occasions: 28 March and 4,11 and 18 April 1990 corresponding to Expts 1 to 4 .

At each station, three $12 \mathrm{l}$ acid-washed polycarbonate bottles were filled on-board, the water being filtered through a $170 \mu \mathrm{m}$ Nylon mesh to remove larger zooplankton, and then kept cool in darkness until further incubation in the laboratory. Each bottle was filled from a different Niskin bottle cast in order to achieve complete independence between replicates. Before sampling, the vertical distribution of temperature was measured with a Braystoke Series 6000 conductivity/temperature meter Once in the laboratory (ca $4 \mathrm{~h}$ after sampling), the 6 bottles were incubated at constant temperature $\left(15^{\circ} \mathrm{C}\right)$ and irradiance $\left(50 \mu \mathrm{E} \mathrm{m}^{-2} \mathrm{~s}^{-1}\right.$; North-Light fluorescent tubes), with a $12 \mathrm{~L} \cdot 12 \mathrm{D}$ photoperiod. Bottles were placed on rollers which rotated them at ca $1 \mathrm{rpm}$ to prevent sedimentation of the cells. Each incubation lasted $7 \mathrm{~d}$.

Chlorophyll concentration was determined twice a day on particulate material retained on $0.2 \mu \mathrm{m}$ Whatman membrane filters. Filters were frozen $\left(-20^{\circ} \mathrm{C}\right)$ until their analysis by fluorometry using a PerkinElmer 3000 spectrofluorometer after extraction in $90 \%$ acetone as in Strickland \& Parsons (1972). Samples to 
monitor changes in nutrients concentration, biochemical composition and phytoplankton abundance were taken 3 times during each experiment (Days 1, 3 and 6$)$. Prefiltered water samples $(0.45 \mu \mathrm{m}$ Whatman membrane filters) for inorganic nutrient (nitrate, phosphate and silicate) determination were analysed with an autoanalyser (nitrate and silicate) or manually (phosphate) following the methods described in Strickland \& Parsons (1972). Samples for cell enumeration and identification were preserved in Lugol's iodine solution and counted under an inverted microscope. Cell counts were converted to carbon equivalents as in Holligan et al. (1984). Only one sample from the triplicates was counted.

Proteins were analysed by the method of Lowry et al. (1951) according to the protocol described in Clayton et al. (1988). Bovine serum albumin was used as standard. Total carbohydrates were quantified by the phenol-sulphuric acid method of Dubois et al. (1956). The concentration of acid-soluble carbohydrates (ASC) was determined by extraction with $0.05 \mathrm{M}$ sulphuric acid at $20^{\circ} \mathrm{C}$ for $1 \mathrm{~h}$ (Myklestad 1978) and further analysis of total carbohydrates in the solution as described above. In both cases, calibration curves were calculated with glucose as standard. Total lipids were analysed by the sulphophosphovanillin method (Barnes \& Blackstock 1973) with cholesterol as standard.

Photosynthetic carbon incorporation into cellular constituents was determined daily. From each experimental bottle, two $60 \mathrm{ml}$ polycarbonate bottles were filled, inoculated with $185 \mathrm{kBq}\left(5 \mu \mathrm{Ci}\right.$ ) of $\mathrm{NaH}^{14} \mathrm{CO}_{3}$ and placed in the same incubator as the larger bottles. After $12 \mathrm{~h}$ incubation, one of the $60 \mathrm{ml}$ bottles was filtered through $0.2 \mu \mathrm{m}$ Whatman membrane filters. Filters were placed in a scintillation vial with $1 \mathrm{ml}$ deionized water and kept frozen $\left(-20^{\circ} \mathrm{C}\right)$ until further analysis. The second bottle was filtered after $24 \mathrm{~h}$ following the same procedure to examine the overnight dark redistribution of labelled intracellular photosynthetic products. The analytical procedure used for fractionating these products has been described in Madariaga \& Fernández (1990). The procedure separates the cell material into 4 fractions: chloroform-soluble compounds (lipids), methanol/water-soluble compounds (low molecular weight metabolites, LMWM), hot trichloroacetic acid (TCA) soluble compounds (carbohydrates and nucleic acids), and hot TCA-insoluble compounds (proteins). In preliminary experiments using this technique, ${ }^{14} \mathrm{C}$ recovery values between 93 and $100 \%$ ( $n=24$ ) were found, as compared to independently measured total carbon fixation.

Dark reallocation for each biochemical compound was calculated from the relative difference in total carbon incorporation between 12 and $24 \mathrm{~h}$ incubations. Isotope uptake data were converted into specific syn- thesis rates (SSR) for the main biochemical compounds according to the equation:

$$
\operatorname{SSR}=\left(\Delta C_{p} / C_{p}\right)
$$

where $\lrcorner C_{p}=$ the amount of carbon incorporated into the given biochemical compound after $24 \mathrm{~h}$ incubation and $\mathrm{C}_{p}=$ the carbon content of the biochemical pool which was assumed to be $53 \%$ of total weight for proteins, based on the amino acid composition of average proteins (Jukes et al. 1975), and 40 and $84 \%$ for carbohydrates and lipids respectively, as calculated from the carbon composition of the standards employed.

All statistical analyses were performed using SAS software (SAS Institute 1985).

\section{RESULTS}

\section{Chlorophyll, nutrients and species composition}

Changes in chlorophyll concentration are shown in Fig. 1, and Tables 1 \& 2 give data for the inorganic nutrient concentrations and biomass of the most abundant phytoplankton species, respectively, in the 4 experiments.

In Expt 1, chlorophyll concentration increased slightly up to Day 4 in both sets of microcosms (Expt 1. Stns L4 and E1. Microcosms 1L4 and 1E1), then decreased. Microflagellates provided most of the phytoplankton

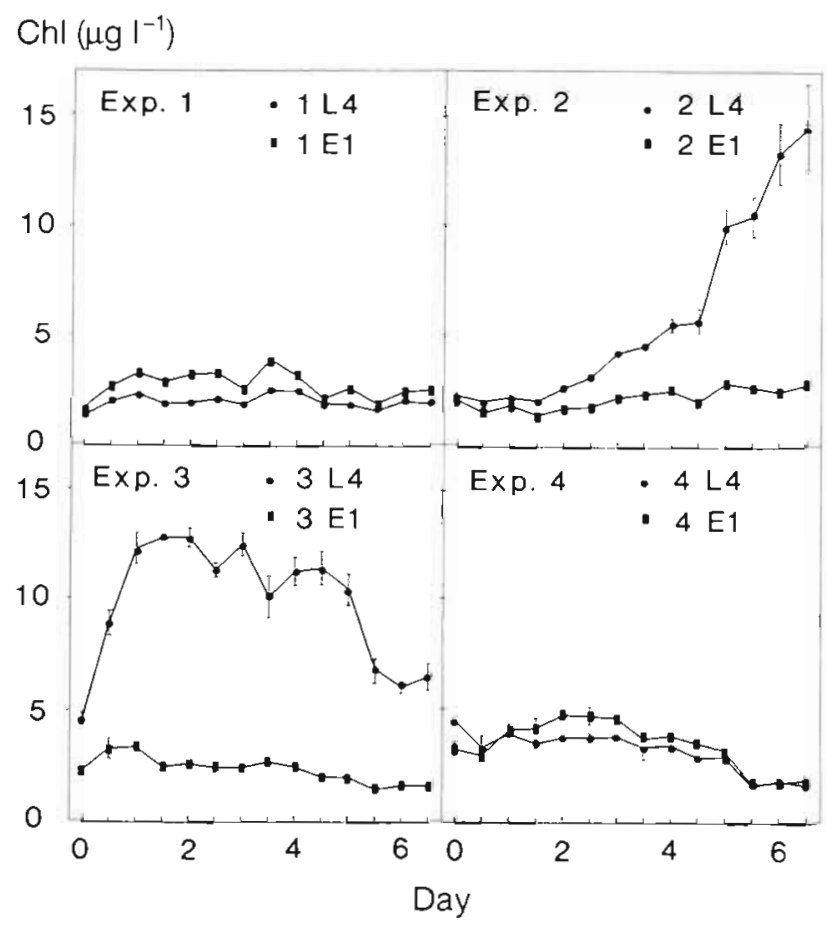

Fig. 1 Changes in chlorophyll concentration in the experimental microcosms. Error bars represent $\pm 1 \mathrm{SE}$ 
Table 1 Concentrations of inorganic nutrients in the experimental microcosms. Concentrations are expressed in $\mu \mathrm{M}$ $( \pm \mathrm{SE} ; \mathrm{n}=3$ )

\begin{tabular}{|c|c|c|c|}
\hline & Nitrate & Phosphate & Silicate \\
\hline \multicolumn{4}{|l|}{ Expt 1} \\
\hline \multicolumn{4}{|c|}{ Microcosm 1L4 } \\
\hline Day 1 & $11.5 \pm 0.2$ & $0.5 \pm 0.0$ & $4.9 \pm 0.0$ \\
\hline 3 & $8.8 \pm 0.2$ & $0.4 \pm 0.0$ & $3.4 \pm 0.1$ \\
\hline 6 & $8.3 \pm 0.1$ & $0.4 \pm 0.1$ & $2.9 \pm 0.1$ \\
\hline \multicolumn{4}{|c|}{ Microcosm 1E1 } \\
\hline Day 1 & $8.5 \pm 0.0$ & $0.4 \pm 0.0$ & $3.6 \pm 0.1$ \\
\hline 3 & $6.7 \pm 0.1$ & $0.2 \pm 0.1$ & $2.5 \pm 0.1$ \\
\hline 6 & $6.2 \pm 0.1$ & $0.3 \pm 0.1$ & $2.0 \pm 0.3$ \\
\hline \multicolumn{4}{|l|}{ Expt 2} \\
\hline \multicolumn{4}{|c|}{ Microcosm 2L4 } \\
\hline Day 1 & $6.9 \pm 0.0$ & $0.5 \pm 0.0$ & $3.0 \pm 0.0$ \\
\hline 3 & $5.6 \pm 0.1$ & $0.3 \pm 0.1$ & $1.9 \pm 0.1$ \\
\hline 6 & $2.7 \pm 0.2$ & $0.1 \pm 0.0$ & $0.1 \pm 0.1$ \\
\hline \multicolumn{4}{|c|}{ Microcosm 2E1 } \\
\hline Day 1 & $5.4 \pm 0.1$ & $0.5 \pm 0.0$ & $2.4 \pm 0.0$ \\
\hline 3 & $5.1 \pm 0.2$ & $0.2 \pm 0.1$ & $2.3 \pm 0.1$ \\
\hline 6 & $4.3 \pm 0.2$ & $0.1 \pm 0.0$ & $2.0 \pm 0.1$ \\
\hline \multicolumn{4}{|l|}{ Expt 3} \\
\hline \multicolumn{4}{|c|}{ Microcosm 3L4 } \\
\hline Day 1 & $2.3 \pm 0.1$ & $0.2 \pm 0.0$ & $0.7 \pm 0.0$ \\
\hline 3 & $0.3 \pm 0.1$ & $0.1 \pm 0.0$ & $0.1 \pm 0.0$ \\
\hline 6 & $0.1 \pm 0.1$ & $0.0 \pm 0.0$ & $0.0 \pm 0.0$ \\
\hline \multicolumn{4}{|c|}{ Microcosm 3E1 } \\
\hline Day 1 & $5.3 \pm 0.3$ & $0.4 \pm 0.0$ & $2.4 \pm 0.1$ \\
\hline 3 & $4.7 \pm 0.6$ & $0.3 \pm 0.0$ & $2.3 \pm 0.4$ \\
\hline 6 & $4.4 \pm 0.1$ & $0.3 \pm 0.0$ & $2.0 \pm 0.0$ \\
\hline \multicolumn{4}{|l|}{ Expt 4} \\
\hline \multicolumn{4}{|c|}{ Microcosm 4L4 } \\
\hline Day 1 & $0.3 \pm 0.1$ & $0.2 \pm 0.0$ & $0.3 \pm 0.0$ \\
\hline 3 & $0.2 \pm 0.1$ & $0.1 \pm 0.0$ & $2.0 \pm 0.0$ \\
\hline 6 & $0.3 \pm 0.1$ & $0.1 \pm 0.0$ & $0.1 \pm 0.0$ \\
\hline \multicolumn{4}{|c|}{ Microcosm 4E1 } \\
\hline Day 1 & $1.7 \pm 0.2$ & $0.3 \pm 0.0$ & $1.8 \pm 0.0$ \\
\hline 3 & $0.3 \pm 0.1$ & $0.1 \pm 0.0$ & $1.6 \pm 0.0$ \\
\hline 6 & $0.8 \pm 0.2$ & $0.1 \pm 0.0$ & $1.5 \pm 0.1$ \\
\hline
\end{tabular}

biomass during this experiment, their relative contribution to the total ranging from 40 to $98 \%$. Diatoms were also significant in the $1 \mathrm{~L} 4$ microcosms. All the measured nutrients were present at relatively high concentrations at the beginning, and decreased throughout the experiment; measurable concentrations still remained on the last day of incubation.

An actively growing phytoplankton population developed during Expt 2 in the 2L4 microcosms, reaching chlorophyll concentrations over $13 \mu \mathrm{gl}^{-1}$ on Day 7 . These high chlorophyll values were due mainly to a mixture of chain-forming diatoms, the most abundant species being medium-sized $(20 \mu \mathrm{m})$ cells of the genus Thalassiosira, Skeletonema costatum, Lauderia borealis and several species of Chaetoceros. Phosphate and silicate were depleted by the last day of incubation, due to the development of the diatom bloom. However, in the microcosms $2 \mathrm{E} 1$ where microflagellates were the dominant group, no bloom was observed, nitrate and silicate showing only small changes, though phosphate decreased from $0.45 \mu \mathrm{M}$ on Day 1 to $0.14 \mu \mathrm{M}$ by the end of the experiment.

In Expt 3, chlorophyll concentration exhibited a sharp increase during the first $24 \mathrm{~h}$ in the $3 \mathrm{~L} 4$ microcosms, reaching $12 \mu \mathrm{g} \mathrm{l}^{-1}$, and then decreased slowly up to the fifth day after which it declined steeply. It is noteworthy that, in this bloom, the species composition on the first day was similar to that at the end of the diatom bloom in Expt 2. A mixed diatom/Phaeocystis $\mathrm{sp}$. assemblage characterized this bloom; diatoms dominated at the beginning of the experiment, contributing up to $77 \%$ of the total biomass. During the following days, while the diatoms exhibited slowed growth, Phaeocystis sp. rapidly increased, reaching very high biomass values by the middle of the week. However, Phaeocystis sp. nevcr cxceeded $50 \%$ of the total carbon biomass. All the inorganic nutrients were present at low concentrations at the beginning, and gradually decreased, becoming completely exhausted by Day 6 . As in Expt 2, there was no significant growth in the microcosms containing E1 water, where microflagellates constituted most of the total phytoplankton biomass and inorganic nutrients remained rather constant throughout the incubation.

In Expt 4, chlorophyll concentration was about $4 \mu \mathrm{g} \mathrm{l}^{-1}$ at the beginning of the incubation in both sets of microcosms (4E1 and 4L4) and declined progressively up to the end of the study period, when less than $2 \mu \mathrm{g} \mathrm{I}^{-1}$ remained. Phaeocystis sp. was the dominant species, especially during the latter half of the experiment, when its contribution exceeded $74 \%$ of the total carbon biomass. In the $4 \mathrm{E} 1 \mathrm{microcosms}$, microflagellates initially represented $95 \%$ of the total carbon biomass. Nutrients, already low at the beginning of this experiment, decreased even further during the subsequent days.

\section{Biochemical composition}

The concentrations of protein, acid-insoluble carbohydrates (AIC), lipid and acid-soluble carbohydrates (ASC) in the experimental microcosms, expressed on a carbon basis, are shown in Table 3 . Very high increases in protein concentration, up to 3 -fold in $7 \mathrm{~d}$, were detected during the diatom bloom in the $2 \mathrm{~L} 4$ microcosms. Slight increases in protein concentration were also found in other experiments. It is noteworthy that the large increase in chlorophyll and Phaeocystis sp. biomass at the beginning of Expt 3 in the 3 L 4 microcosms was not paralleled by an increase in protein- $C$ concentration. The highest observed increases in AIC-C 


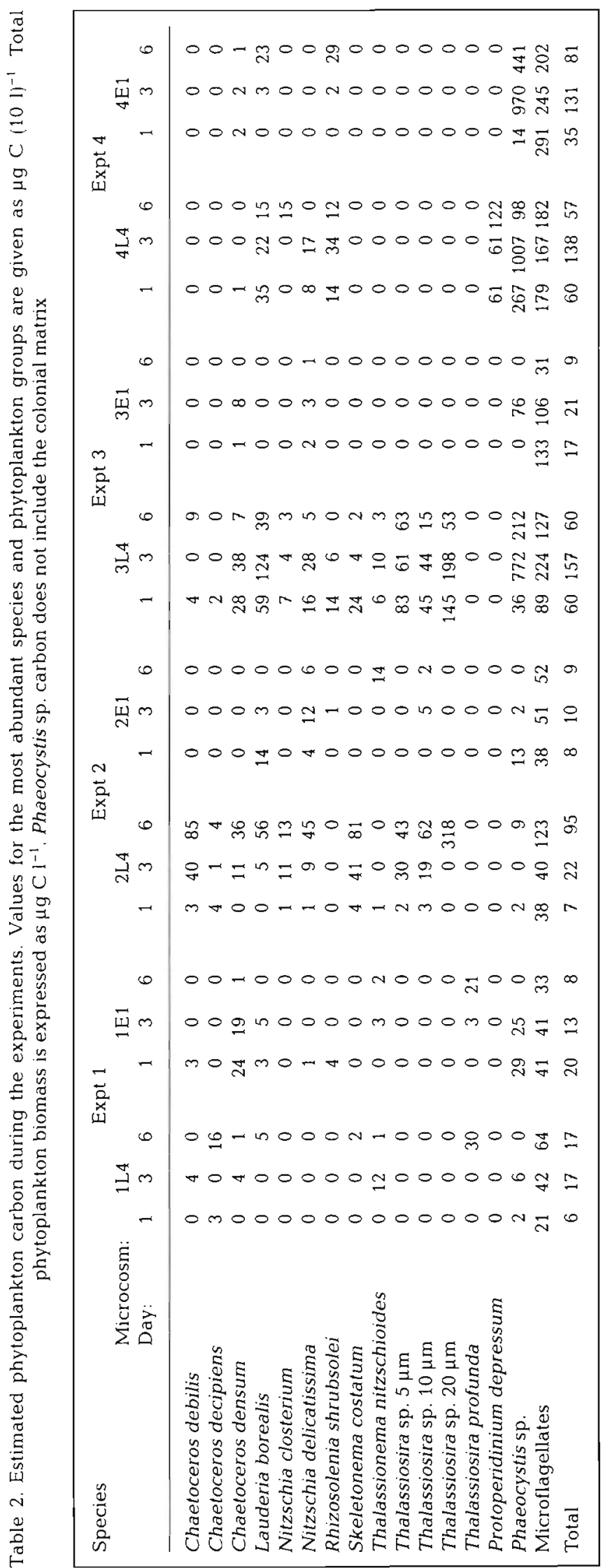

Table 3. Concentration of protein-C (PROT), acid-insoluble carbohydrate-C (AIC), lipid-C (LIP) and acid-soluble carbohydrate-C (ASC) in the experiments. Concentrations are expressed in $\mu \mathrm{g} \mathrm{Cl}^{-1}\left( \pm 1 \mathrm{SE}_{i} \mathrm{n}=3\right)$

\begin{tabular}{|c|c|c|c|c|}
\hline & PROT & AIC & LIP & ASC \\
\hline \multicolumn{5}{|l|}{ Expt 1} \\
\hline \multicolumn{5}{|c|}{ Microcosm 1L4 } \\
\hline Day 1 & $29 \pm 3$ & $23 \pm 3$ & $107 \pm 14$ & $0.0 \pm 0.0$ \\
\hline 3 & $53 \pm 11$ & $33 \pm 0$ & $82 \pm 12$ & $0.4 \pm 0.3$ \\
\hline 6 & $42 \pm 5$ & $25 \pm 5$ & $151 \pm 33$ & $3.4 \pm 3.4$ \\
\hline \multicolumn{5}{|c|}{ Microcosm 1E1 } \\
\hline Day 1 & $45 \pm 6$ & $23 \pm 2$ & $55 \pm 7$ & $0.4 \pm 0.4$ \\
\hline 3 & $48 \pm 1$ & $48 \pm 3$ & $88 \pm 5$ & $1.5 \pm 1.2$ \\
\hline 6 & $70 \pm 10$ & $53 \pm 9$ & $173 \pm 27$ & $2.0 \pm 0.2$ \\
\hline
\end{tabular}

\section{Expt 2}

Microcosm 2L4

\begin{tabular}{ccccc} 
Day 1 & $38 \pm 3$ & $19 \pm 2$ & $72 \pm 7$ & $1.4 \pm 0.4$ \\
3 & $92 \pm 5$ & $54 \pm 3$ & $102 \pm 9$ & $2.6 \pm 0.7$ \\
6 & $111 \pm 5$ & $89 \pm 5$ & $82 \pm 28$ & $27 \pm 5$ \\
\multicolumn{1}{c}{$\begin{array}{c}\text { Microcosm } \\
\text { 2E } 1\end{array}$} & & & \\
Day 1 & $56 \pm 2$ & $28 \pm 7$ & $134 \pm 12$ & $3.0 \pm 0.5$ \\
3 & $61 \pm 7$ & $62 \pm 14$ & $84 \pm 4$ & $3.8 \pm 1.0$ \\
6 & $80 \pm 2$ & $68 \pm 18$ & $125 \pm 36$ & $0.5 \pm 0.3$
\end{tabular}

Expt 3

Microcosm 3L4

\begin{tabular}{|c|c|c|c|c|}
\hline & & & & \\
\hline Day 1 & $51 \pm 8$ & $43 \pm 1$ & $78 \pm 24$ & $11 \pm 0.4$ \\
\hline 3 & $49 \pm 3$ & $304 \pm 5$ & $119 \pm 13$ & $204 \pm 14$ \\
\hline 6 & $68 \pm 5$ & $304 \pm 27$ & $213 \pm 49$ & $187 \pm 13$ \\
\hline \multicolumn{5}{|c|}{ Microcosm 3E1 } \\
\hline Day 1 & $40 \pm 4$ & $14 \pm 2$ & $105 \pm 17$ & $1.4 \pm 1.4$ \\
\hline 3 & $35 \pm 4$ & $48 \pm 1$ & $126 \pm 29$ & $2.6 \pm 0.2$ \\
\hline 6 & & $31 \pm 8$ & $183 \pm 35$ & $17 \pm 7$ \\
\hline
\end{tabular}

\section{Expt 4}

Microcosm 4L4

$\begin{array}{ccccc}\text { Microcosm } & 4 L 4 & & & \\ \text { Day } 1 & 43 \pm 7 & 121 \pm 5 & 184 \pm 55 & 61 \pm 5 \\ 3 & 50 \pm 5 & 249 \pm 12 & 162 \pm 31 & 121 \pm 6 \\ 6 & 41 \pm 2 & 140 \pm 11 & & 53 \pm 13 \\ \text { Microcosm } & 4 \mathrm{E} 1 & & & \\ \text { Day 1 } & 53 \pm 1 & 53 \pm 4 & 134 \pm 31 & 28 \pm 8 \\ 3 & 82 \pm 2 & 253 \pm 14 & 219 \pm 40 & 147 \pm 6 \\ 6 & 48 \pm 0 & 174 \pm 28 & & 85 \pm 17\end{array}$

concentration occurred during the growth phases of Phaeocystis sp., mainly during the early stages in the $3 \mathrm{~L} 4$ and $4 \mathrm{E} 1$ microcosms, where a 5 - to 7 -fold increase within $3 \mathrm{~d}$ was observed. Lipid-C concentration was relatively high during bloom periods and showed a consistently upward trend towards the end of the diatom and Phaeocystis sp. blooms. The concentration of ASC-C remained very low in the experiments where active growth was not observed. A significant increase was measured on the last day of the diatom bloom in the 2L4 microcosms, when this biochemical pool contributed more than $8 \%$ of the total carbon in the 4 measured components. Large amounts of ASC-C were found in Phaeocystis sp.dominated experiments ( 3 and 4 ), reaching up to $30 \%$ of the total carbon. 
The plot of protein-C concentration against chlorophyll concentration for the complete set of samples is presented in Fig. 2. There was a hyperbolic relationship between the 2 variables, except for 3 samples

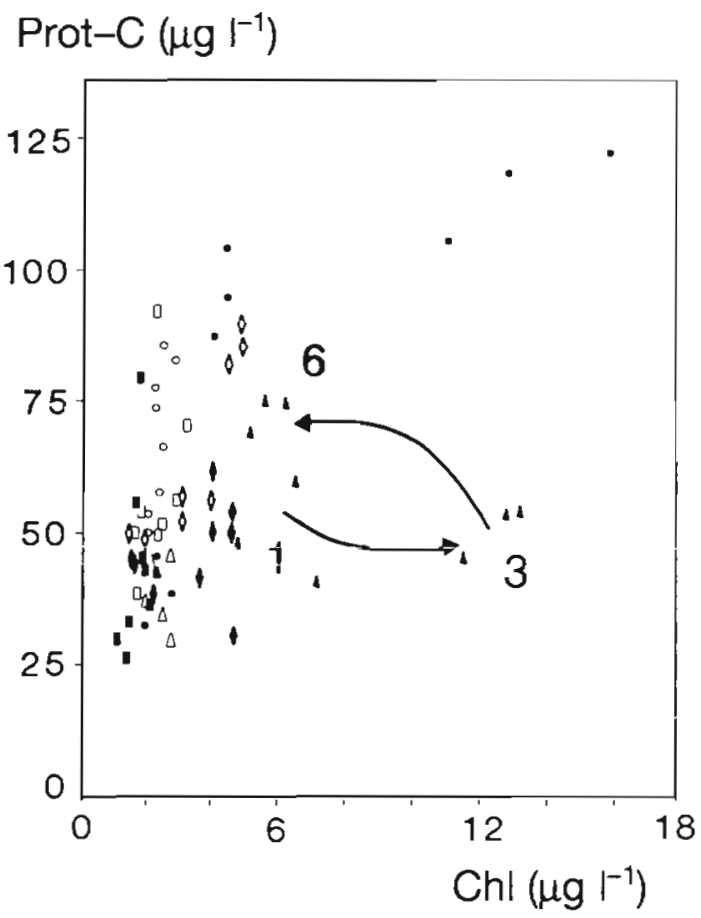

Fig. 2. Plot of protein-C against chlorophyll concentration for all the samples during the experiments. Symbols represent different experimental microcosms as shown in Fig. 3. The arrows indicate the changes in the pratein-C/chlorophyll ratio on Days 1, 3 and 6 in the 3L4 microcosms which had extremely low protein-C/chlorophyll ratios and corresponded to the period of maximum Phaeocystis sp. biomass (Day 4 ) in the 3L 4 microcosms. When these samples were excluded, a statistically significant fit of the hyperbolic function Prot. $\mathrm{C}=(\mathrm{a} \mathrm{Chl}) /(b+\mathrm{Chl})$ was obtained $(F=379.8, \mathrm{p}<0.001, \mathrm{n}=62)$. The estimated parameters were $a=124 \pm 16( \pm 1 \mathrm{SE})$ and $b=3.5$ \pm 0.9 ( $\pm 1 \mathrm{SE})$.

A summary of the major differences in biochemical composition among the phytoplankton assemblages monitored in this study is provided in Fig. 3, where samples are represented according to their protein-C/ AIC-C ratio and the percentage of carbon present in ASC. Three groups can be identified. Samples corresponding to non-growing periods, i.e. those dominated by microflagellates (1E1, 2E1, 3E1, 1L4 microcosms) and during the early stages of the diatom bloom in the 2L4 microcosm, contained very low or negligible proportions of carbon in ASC. The protein-C/ AIC-C ratio within this group displayed a wide range of values. A second group, formed by the final stages of the diatom bloom and the early phases of the Phaeocystis sp. bloom in the 3L4 microcosm, displayed an ASC content of about $10 \%$, and a protein-C/AIC-C ratio close to unity. The third group was characterized by an extremely high contribution of ASC-C to total carbon (between 20 and $40 \%$ ) and protein-C/AIC-C ratios lower than 0.5 . This group was formed by the declining phases of Phaeocystis sp. blooms in the 3L4, $4 \mathrm{~L} 4$ and $4 \mathrm{E} 1$ microcosms.

\section{$\%$ ASC-C}

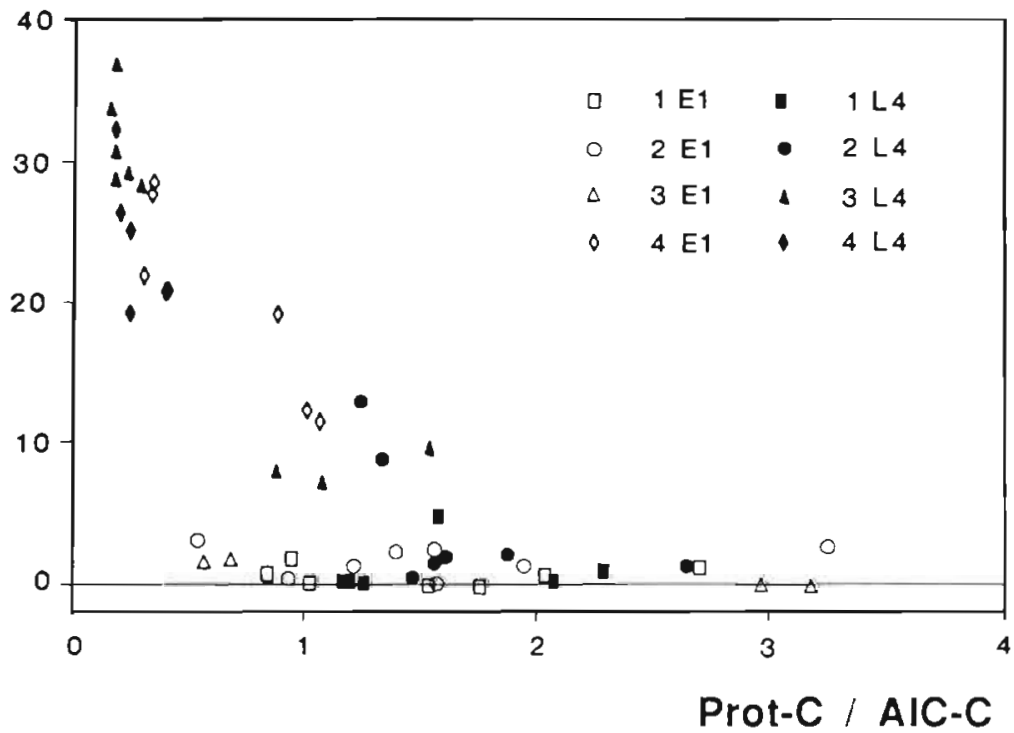

Fig. 3. Plot of the Prot.C/AIC-C ratio against the percentage of ASC-C

\section{${ }^{14} \mathrm{C}$ incorporation into end products}

Patterns of ${ }^{14} \mathrm{C}$ incorporation into the end-products of photosynthesis during the experiments are presented in Figs. 4 \& 5 for L4 and E1 microcosms respectively. In all the experiments LMWM exhibited the highest percentage of ${ }^{14} \mathrm{C}$ incorporation. This percentage was significantly higher in the Phaeocystis sp.-dominated assemblages (3L4, 4L4 and 4E1 microcosms). The relative incorporation of ${ }^{14} \mathrm{C}$ into lipids was also significant, with a marked increase during the final stages of Expts 3 and 4 . The proportion of carbon incorporation into proteins was highly variable among experiments. Thus, values between $20 \%$ and $35 \%$ were measured during the diatom bloom which developed in the $2 \mathrm{~L} 4$ microcosms. In contrast, the relative incorporation of carbon into proteins was below $10 \%$ in the experiments where Phaeocystis sp. became 
$\% \mathrm{C}$ inc

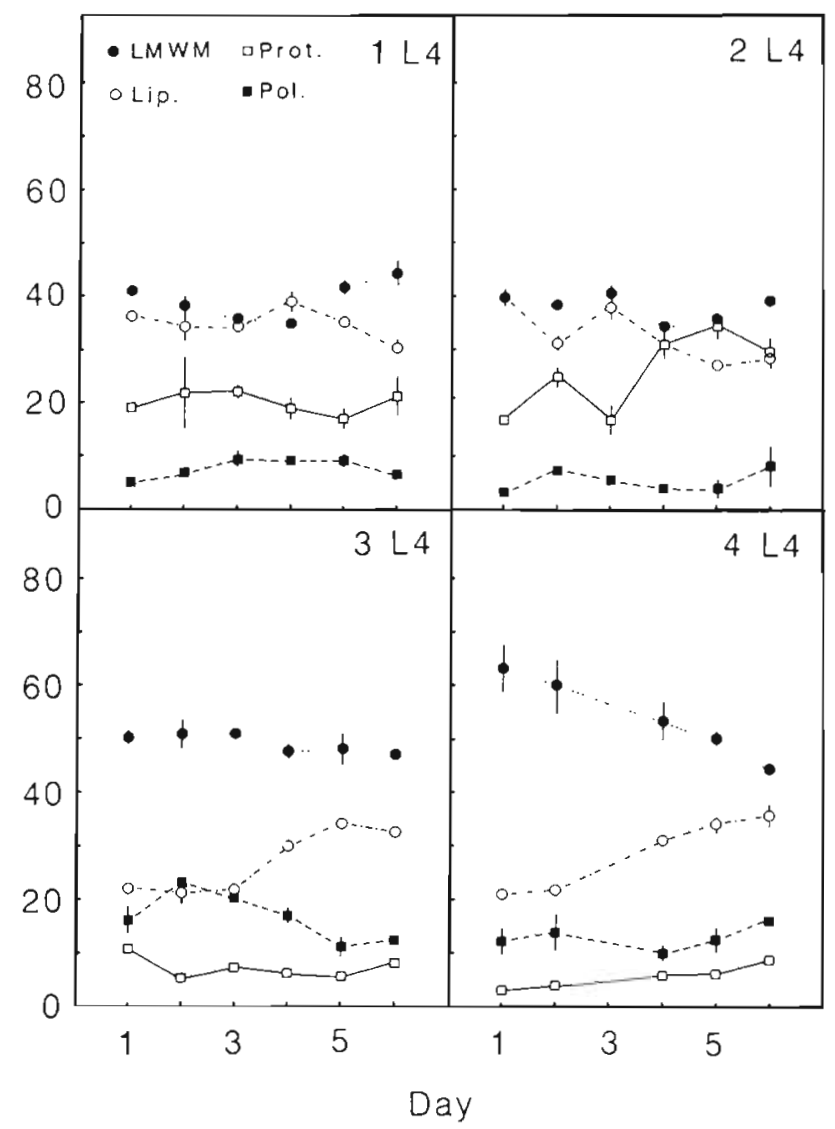

Fig. 4. Relative incorporation of ${ }^{14} \mathrm{C}$ into proteins (Prot.), polysaccharides (Pol.), lipids (Lip.) and LMWM in the L4 microcosms during the 4 experiments. Error bars represent $\pm 1 \mathrm{SE}$

the most abundant population (3L4, 4L4 and 4E1 microcosms). Carbon incorporation into polysaccharides was very low in the first and second experiments, but increased when Phaeocystis sp. dominated.

Specific carbon incorporation into proteins, polysaccharides and lipids measured during light and lightdark incubations is presented in Fig. 6 for a nongrowing microflagellate assemblage (1E1), the diatom bloom (2L4), and the mixed diatom/Phaeocystis sp. bloom (3L4). Specific carbon incorporation into proteins was very low during non-growing periods, values

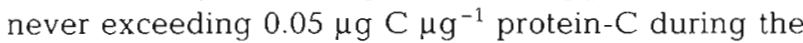
light or combined light-dark periods. The highest values for specific carbon incorporation into protein were measured on the first day in the 3L4 microcosms, when diatoms were the dominant phytoplankton group. The diatom bloom, which developed in the 2L4 microcosms, displayed intermediate values between the other 2 experiments. Specific carbon incorporation into polysaccharides and lipids behaved in a similar way to that of proteins. The highest light-dark changes
$\% \mathrm{C}$ inc.

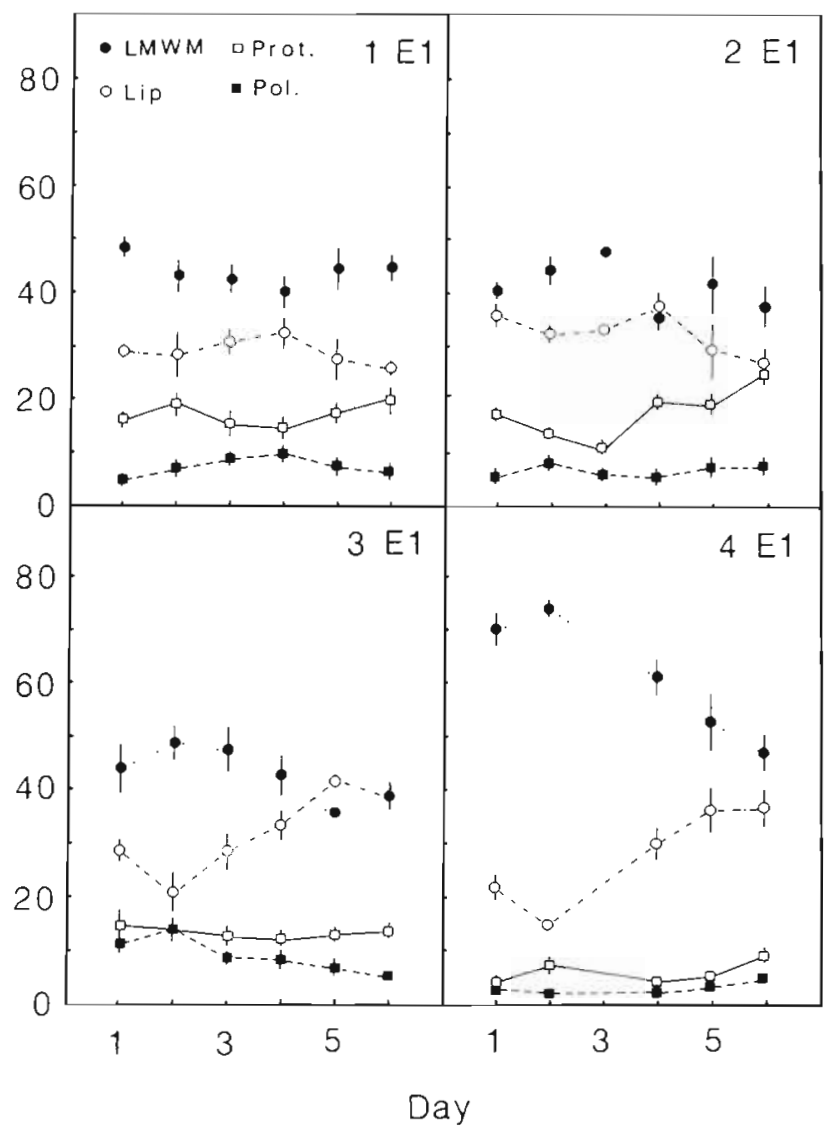

Fig. 5. Relative incorporation of ${ }^{14} \mathrm{C}$ into proteins (Prot.), polysaccharides (Pol.), lipids (Lip.) and LMWM in the E1 microcosms during the 4 experiments. Error bars represent $\pm 1 \mathrm{SE}$

in specific carbon incorporation into proteins were measured during the development of the diatom bloom (2L4 microcosms). Dark losses of protein were noted during the early and exponential stages (Days 1 and 3) of this bloom, whereas on the last day, and coincident with the highest specific carbon incorporation into proteins measured during that period, dark protein losses were not significant. Specific carbon incorporation into polysaccharides decreased during the dark period. This pattern, however, was not observed for lipids, for which the small differences between light and light/dark periods were not significant.

Principal component analysis (PCA) was performed in order to summarize the general trends observed in ${ }^{14} \mathrm{C}$ incorporation into biopolymers during the experiments. Only those data corresponding to $24 \mathrm{~h}$ incorporation were used. Two principal components were extracted from the analysis, explaining 56.7 and $22.8 \%$ of the total variance respectively (Table 4 ). The first component (PC1) was positively correlated with the percentage of carbon incorporation into proteins 

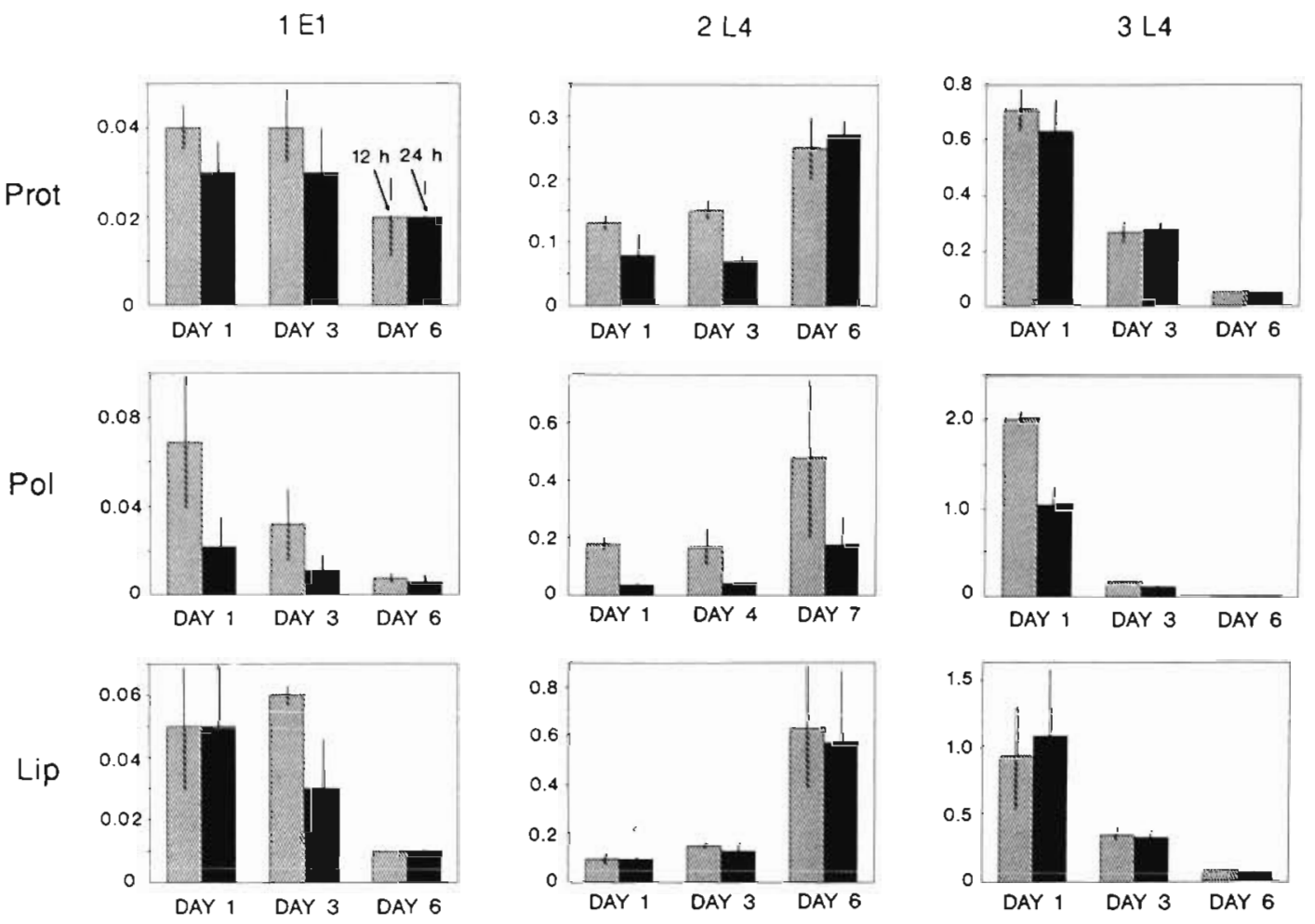

Fig. 6. Specific carbon incorporation into the biochemical pools: proteins (Prot), polysaccharides (Pol) and lipids (Lip) after light $(12 \mathrm{~h})$ and light-dark $(24 \mathrm{~h})$ incubations. Temporal variations are shown for a non-growing microflagellate assemblage (1E1), a diatom bloom (2L4) and a mixed diatom Phaeocystis/sp. bloom (3L4). Error bars represent $\pm 1 \mathrm{SE}$

and lipids and negatively with that of polysaccharides and LMWM. Carbon incorporation into polysaccharides and, to a lesser extent, into proteins showed positive correlations with the second principal component.

In Fig. 7, the plot of the samples on the first 2 factorial axes is shown. Samples were divided, according to the species composition and temporal occurrence, into 6 groups (I to VI). Samples belonging to Group I corre- sponded to non-growing microflagellate assemblages and showed a scatter distribution in the factorial space. In general, these samples reached positive loadings on PC1 and either negative or positive on PC2. This pattern suggests that, as might be expected from their taxonomic heterogeneity, the microflagellates were not a metabolically homogeneous group. Groups II and III represent pre-diatom and diatom bloom samples

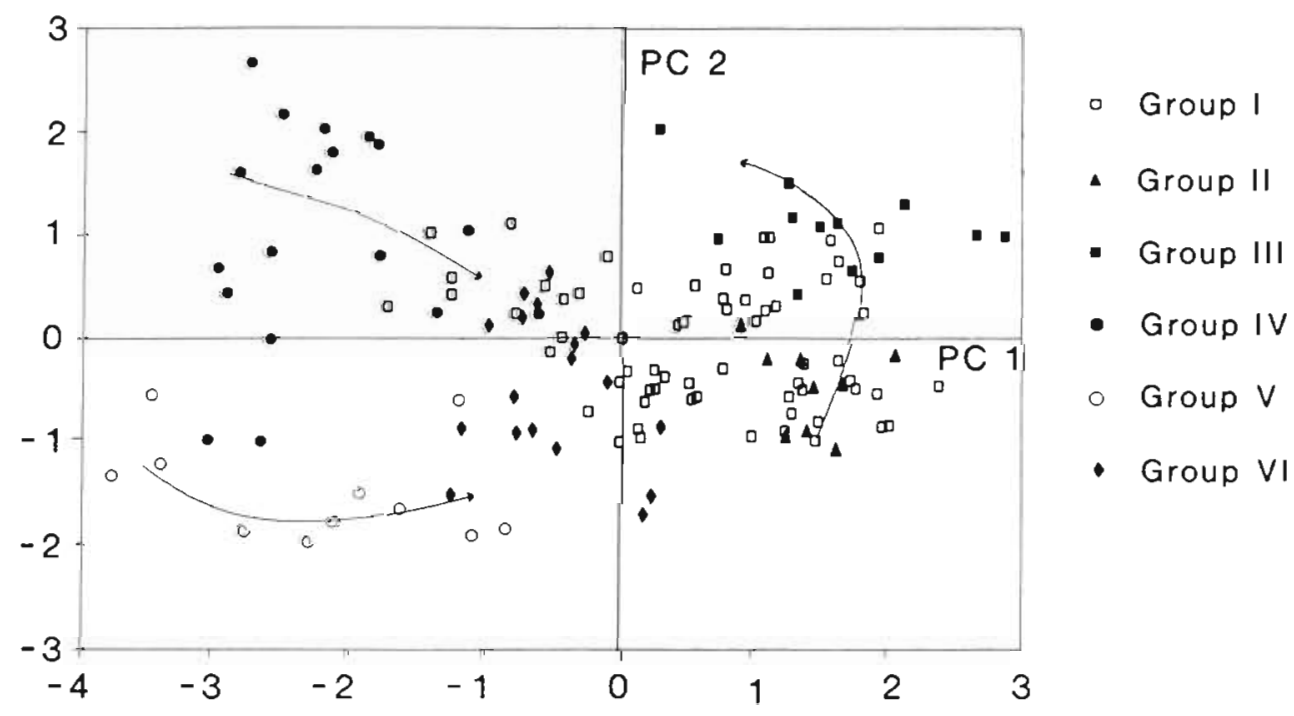

Fig. 7 Plot of the samples on the factorial space defined by the 2 principal components ( $\mathrm{PC} 1$ and $\mathrm{PC} 2$ ) extracted from the PCA performed on the relative incorporation of ${ }^{14} \mathrm{C}$ into macromolecules after $24 \mathrm{~h}$ incubations (see Table 4). Symbols represent phytoplankton Groups I to VI derived from the position of the samples in the factorial space. For explanation see text 
Table 4. Correlation between the percentages of $C$ incorporation into protein, polysaccharide, lipid and LMWM on the 2 first factorial axes (PC1 and PC2) obtained from principal component analysis (for explanation see text). The percentage of variance explained by each factor is shown in parentheses

\begin{tabular}{|lcc|}
\hline & PC1 & PC2 \\
& $(56.7 \%)$ & $(22.8 \%)$ \\
\hline Protein & 0.53 & 0.41 \\
Polysaccharide & -0.38 & 0.71 \\
Lipid & 0.47 & -0.40 \\
LMWM & -0.59 & -0.40 \\
\hline
\end{tabular}

respectively. These samples corresponded to the growth period in the $2 \mathrm{~L} 4$ microcosms and the early phases in the $3 \mathrm{~L} 4$ microcosms. The diatom bloom was characterized by a transition from relatively high carbon incorporation into lipids (low scores in both components) to high incorporation into proteins (high positive scores in both components), as the bloom developed. The mixed diatom/Phaeocystis sp. assemblages observed during the growth phase of Phaeocystis sp. in the $3 \mathrm{~L} 4$ and $4 \mathrm{~L} 4$ microcosms are repre- sented by Group IV. This group reached negative scores on PC1 and positive ones on PC2. This distribution indicates relatively high carbon incorporation into polysaccharides and LMWM. Group $V$ was formed by the almost monospecific Phaeocystis sp. populations that developed in the $4 \mathrm{E} 1$ microcosms. This group had negative values in both components as a result of reduced carbon incorporation into polysaccharides with respect to Group IV. As the mixed diatom/ Phaeocystis sp. and Phaeocystis sp. populations declined, their labelling patterns changed sharply, giving rise to Group VI. The positions of the samples belonging to this group on the principal components were close to the factorial space where the non-growing assemblages were clustered.

\section{Metabolic succession}

Fig. 8 provides a summary of the main variations in photosynthetic carbon metabolism and biochemical composition associated with the microflagellatediatom - Phaeocystis sp. succession. The 6 groups (I to
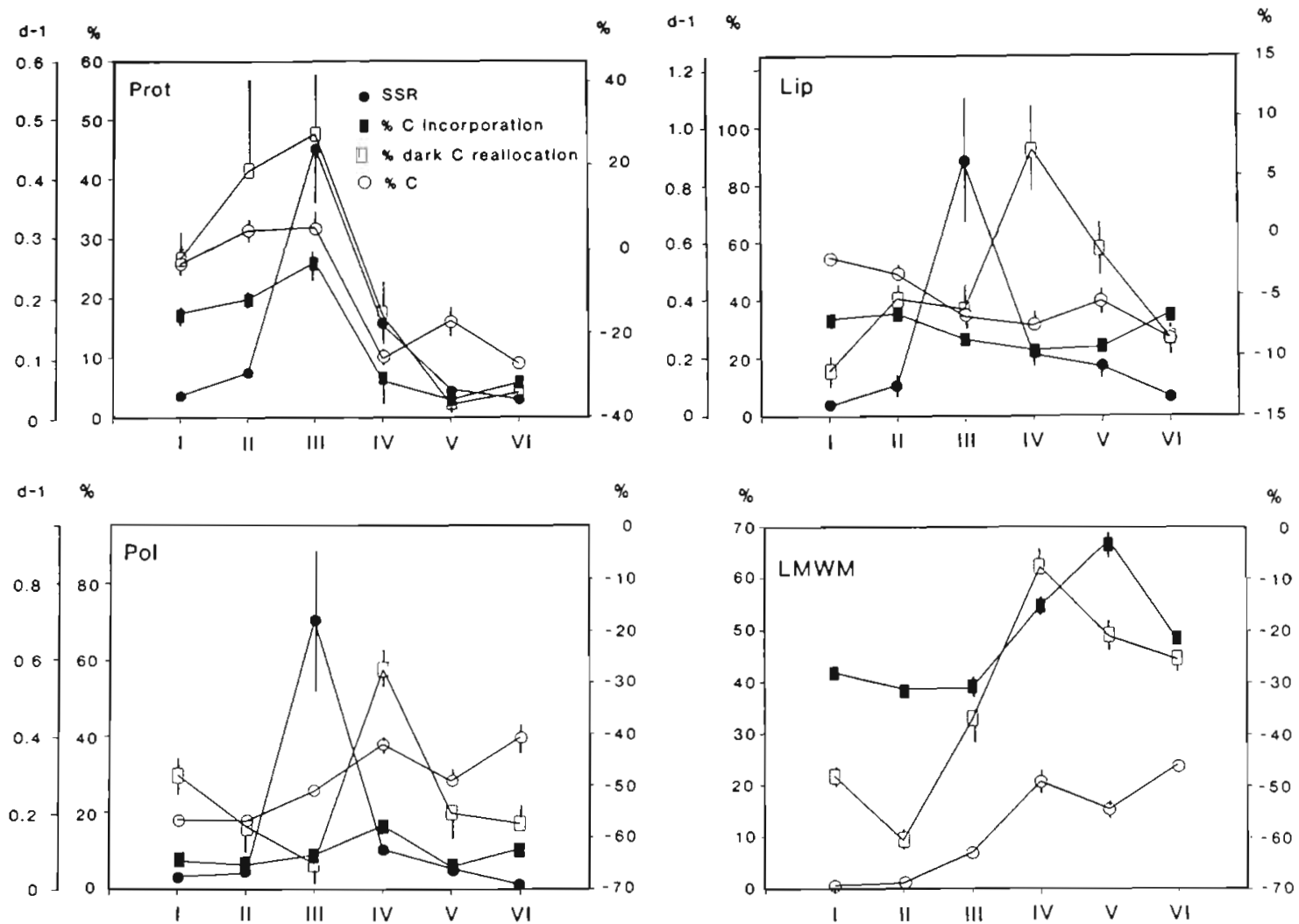

Fig. 8. Specific synthesis rate $\left(\mathrm{d}^{-1}\right)$ and $\%{ }^{14} \mathrm{C}$ incorporation (left-hand scale), \% dark $\mathrm{C}$ reallocation (right-hand scale) and $\% \mathrm{C}$ content (left-hand scale) in the protein (Prot), polysaccharide (Pol) and lipid (Lip) pools. SSR of LMWM was not calculated. $\% \mathrm{C}$ in the LMWM pools refers to ASC-C concentration. Groups I to VI represent the phytoplankton groups derived from the PCA in Fig. 7. Error bars represent $\pm 1 \mathrm{SE}$ 
VI) in the figure were those which emerged from the PCA performed on the percentage of labelling of the different macromolecules; they are ordered according to their temporal succession. Daily specific synthesis rates for the biochemical pools showed their highest values in the diatom-dominated Group III. Maximum rates were $0.45 \pm 0.10,0.70 \pm 0.23$ and $0.88 \pm 0.30 \mathrm{~d}^{-1}$ ( $\pm \mathrm{SE}$ ) for proteins, polysaccharides and lipids, respectively. Variation of protein SSR among groups paralleled that of the percentage of carbon incorporation into proteins and reflected the proportion of carbon present as protein with respect to the total carbon in the 4 measured biochemical pools. In this successional period, relatively high carbon incorporation into protein was also detected during darkness (up to $20 \%$ of that in the light). The relative contribution of AIC-C and the percentage of ${ }^{14} \mathrm{C}$ incorporation into this pool displayed an increasing trend throughout the temporal succession. The highest percentage of polysaccharide dark reallocation was noted during the diatom bloom, coinciding with the maximum occurrence of dark protein synthesis. The percentage of lipid-C varied from $60 \%$ in Group I to $30 \%$ in Group VI, thus showing a slight but continuous decrease throughout the succession. However, this decreasing trend reflected enhanced AIC-C concentration in the Phaeocystis sp.dominated assemblages rather than a decrease in absolute lipid-C concentration (see Table 4). A clear parallelism between the variation patterns of lipid-C and the relative incorporation of ${ }^{14} \mathrm{C}$ into this pool was also observed in this case. The percentage of lipid dark reallocation was generally small. Net synthesis of lipids in darkness was observed in the mixed diatom/Phaeocystis sp. bloom (3L4 microcosms).

Fig. 8 also shows the successional changes in LMWM variables. As the concentrations of LMWM were not measured, the SSR for this pool could not be estimated. Relative flows of ${ }^{14} \mathrm{C}$ into LMWM of up to $70 \%$ of total incorporated carbon were measured in Groups IV to VI, i.e. during the Phaeocystis sp. phase of succession. The variations in the percentage of ASC-C clearly showed the same pattern, reaching values up to $20 \%$ of total carbon in these successional groups. The relative dark reallocation of LMWM followed a similar trend, with higher dark redistribution occurring in the early successional stages.

\section{DISCUSSION}

\section{Bloom development and methodological limitations}

The enclosing of natural plankton assemblages in experimental meso- or microcosms often leads to outbursts of phytoplankton biomass followed by a decline as the nutrients become depleted (e.g. Morris et al. 1983, Hama et al. 1988a, Madariaga \& Fernández 1990). According to the critical depth model for spring bloom triggering (Sverdrup 1953), it might be expected that phytoplankton populations sampled in a mixed nutrient-rich water column during winter-spring would show increases in biomass during incubation under constant environmental conditions as a consequence of the stability of the ambient light in the incubator. In this study, however, phytoplankton outbursts in the microcosms took place only when the populations collected for the experiments also bloomed at sea in the same sampling period (Davies et al. 1992), even though bloom-forming species of diatoms such as Chaetoceros densum, Lauderia borealis and Thalassiosira spp. were present in the 1L4, 1E1 and 2E1 microcosms, where no growth took place (Table 2). The results presented in this study do not allow us to formulate a reliable explanation for this. However, they suggest that other factors apart from irradiance and depth of the mixed layer should be taken into account in elucidating the mechanisms initiating the spring outburst.

Experimentation under controlled conditions is always coupled to limitations derived from the impossibility of completely simulating the complex interactions between environmental factors occurring in nature and this fact needs to be considered when interpreting the results. In these experiments, although nutrient levels were not manipulated, the incubation temperature was higher than that measured at sea $\left(9.9\right.$ to $10^{\circ} \mathrm{C}$ in the upper $\left.40 \mathrm{~m}\right)$, and irradiance $\left(50 \mu \mathrm{E} \mathrm{m}^{-2} \mathrm{~s}^{-1}\right)$ corresponded to depths of 15 to $30 \mathrm{~m}$ during the field study (Davies et al. 1992). Thus, although the sampling depth for the experiments was $10 \mathrm{~m}$ (mean irradiance $190 \mu \mathrm{E} \mathrm{m}^{-2} \mathrm{~s}^{-1}$ ), the natural populations would have been subjected to levels of irradiance close to the experimental value due to vertical mixing.

Another uncertainty emerges when measurements of specific synthesis rates of macromolecular pools in natural phytoplankton populations are made, given the possibility that non-plant material may be present in the samples. An attempt was made to determine the contribution of this material to the total phytoplankton biomass using the relationship between protein-C and a component specific to phytoplankton, i.e. chlorophyll. The relationship between these 2 variables showed a significant fit to a hyperbolic function with an intercept of $38.2 \pm 16.3 \mu \mathrm{g}$ Prot. $-\mathrm{C}$ (Fig. 2). The average chlorophyll/protein-N ratio in our samples was $2.93 \pm 0.16$ $( \pm 1 \mathrm{SE})$, i.e. the same as that reported by Dortch \& Packard (1989) $(2.88 \pm 0.09 ; 1 \mathrm{SE})$ for samples of nearly pure phytoplankton composition. Some of the values, mainly those where Phaeocystis sp. was dominant, showed much higher values for reasons discussed 
later However, the ratio indicates that the SSR values determined in this study are realistic.

The containment of the phytoplankton populations in the microcosms did not seriously influence species succession, which paralleled that observed at sea: microflagellates, which dominated at the beginning of the study, were followed by a multispecific population of chain-forming diatoms, and these by a bloom of Phaeocystis sp. (Davies et al. 1992).

\section{General patterns of photosynthetic carbon metabolism}

As a general rule in all the experiments and especially for non-growing periods, the highest proportion of ${ }^{14} \mathrm{C}$ was incorporated into the LMWM and lipid fractions (Figs. 4 \& 5). High ${ }^{14} \mathrm{C}$ incorporation into LMWM is frequently associated with growth limitation by various environmental factors due to the reduction in the rate of macromolecule synthesis from metabolic precursors. In this regard, observations made both in culture and under natural conditions showed that phytoplankton living at low light levels, as was the case for the late winterearly spring assemblages sampled in this study, displayed higher carbon incorporation into LMWM and lipids than populations adapted to higher irradiances (Harding et al. 1985). Low light may also account for the usually negligible levels of protein synthesis in darkness recorded in the experiments (Figs. $6 \& 8$ ), since dark protein synthesis is a function of the available irradiance during the preceding light period (Lancelot \& Mathot 1985). In addition, species-specific labelling patterns might also account for the general patterns of carbon distribution observed in this study. Thus, small-sized phytoplankton such as microflagellates, which were dominant in some of the experimental microcosms (1 L 4 , 2E1, 3E1), has been reported to incorporate a higher percentage of carbon into lipids than larger cells such as diatoms (Madariaga \& Fernández 1990).

In all the experiments, a proportion of the polysaccharides synthesized during the light period was metabolized in darkness (Figs. 6 \& 8). The same pattern was not observed for lipid incorporation (Figs. 6 \& 8). Lipid dark reallocation was low or negligible during most of this study. These findings are consistent with the higher rates of polysaccharide catabolism with respect to lipid catabolism found in mixed diatom populations (Lancelot \& Mathot 1985).

\section{The diatom bloom}

The general labelling patterns of photosynthetic carbon fixation exhibited by non-growing assemblages changed sharply during the diatom bloom which developed in the 2L4 microcosms (Fig. 4) and also in Phaeocystis sp.-dominated populations in the later experiments (Figs. 5 \& 6). The most relevant fea. ture of the diatom bloom in Expt. 2 was the relatively high proportion of ${ }^{14} \mathrm{C}$ assimilated into proteins (Fig. 5). Similar results have been reported in previous studies carried out with diatom populations enclosed in microcosms (Hama et al. 1988a, Madariaga \& Fernández 1990) and during bloom events occurring both after upwelling events (Barlow 1982, 1984) and in temperate waters during spring (Hitchcock 1978, Madariaga et al. 1991). The highest relative ${ }^{14} \mathrm{C}$ incorporation into proteins was found during the late phase of growth of the bloom in 3L4 and 2L4 microcosms (Fig. 4) where, even though the nitrate concentration was still above $2 \mu \mathrm{M}$, population growth was slowing. The average protein-SSR estimated for actively growing blooming diatom populations in this study was $0.46 \mathrm{~d}^{-1}$ which represents a doubling time of ca $2.2 \mathrm{~d}$. This value its within the range of values reported in the literature for diatom blooms (Hitchcock 1978, Hama et al. 1988a, b) and is also consistent with the increase in protein- $C$ observed in the 2L4 microcosms (Table 3).

The protein/total polysaccharide ratio is known to decrease during the stationary phase of diatom blooms due to accumulation of the storage carbohydrate $\beta-1-3$ glucan as a result of nutrient limitation (Haug et al. 1973). The highest concentration of ASC observed during the diatom bloom in the 2L4 microcosms occurred when phosphate and silicate were depleted and the cells were at the end of the exponential phase (Table 3). The protein/acid-insoluble polysaccharide ratio showed a slight decrease during the same bloom; this is in agreement with the results reported by Myklestad (1977) who found a decrease in the protein/total polysaccharide ratio in exponentially growing cultures of Chaetoceros affinis and Skeletonema costatum under phosphorus-limited conditions.

\section{The Phaeocystis sp. bloom}

The initial phases of growth of Phaeocystis sp. (Group IV) in the $3 \mathrm{~L} 4$ microcosms displayed 3 metabolic characteristics: (1) an abnormally low protein/ polysaccharide ratio on the first day of development of the bloom (Day 3, 3L4 microcosms); (2) extremely high synthesis of acid-soluble and acid-insoluble carbohydrates; and (3) enhanced ${ }^{14} \mathrm{C}$ incorporation into polysaccharides and LMWM, as compared to the other experiments. These patterns of metabolic flows are in accord with the model of Phaeocystis sp. bloom development proposed by Davies et al. (1992). They hypothesized that Phaeocystis sp. cells which reached the bottom after the bloom of the previous year would 
overwinter there in a dormant condition, such as benthic stages or microzoospores, until triggered into growth when light levels reaching the substrate exceeded a threshold value

The present data suggest that, after the triggering of the resting stages, chlorophyll would be rapidly synthesized, resulting in an acceleration in the rate of cellular photosynthesis. This process would lead to an increase of reducing power which would be directed mainly towards the synthesis of carbohydrates. This physiological adaptation would account for the extremely low protein-C/chlorophyll ratios found on Day 3 in the 3 L 4 microcosms (Fig. 2) where a large increase in Phaeocystis sp. biomass was observed (Table 2), but this was not paralleled by a simultaneous increase in either the percentage of ${ }^{14} \mathrm{C}$ incorporated into protein or in the protein-C content.

Concurrently with the rapid chlorophyll synthesis, Phaeocystis sp. cells began to produce large amounts of acid-soluble and acid-insoluble carbohydrates (Table 3); both high and low molecular weight carbohydrates have been shown to be present in the colonial matrix of Phaeocystis sp. (Guillard \& Hellebust 1971). It should be noted here that up to $50 \%$ of reserve acidsoluble carbohydrates are extracted by the chloroformmethanol mixture employed in the ${ }^{14} \mathrm{C}$ fractionation technique to extract LMWM and lipids (McConville et al. 1985). Therefore, a high proportion of the ${ }^{14} \mathrm{C}$ incorporated into the carbohydrates would be recovered with the lipid and, particularly, the LMWM fractions. Thus, the high relative ${ }^{14} \mathrm{C}$ incorporation into LMWM observed during the growth phase of Phaeocystis sp. can be associated with the spectacular increase in reserve acid-soluble carbohydrates. This implies that a high proportion of the carbon incorporated by Phaeocystis sp. during its growth phase is directed towards the formation of the colonial matrix (Fig. 8, Group IV) as the number and sizes of the colonies increase. In this connection, Skreslet (1988) found that under experimental conditions, there was a positive correlation between colony size and rising velocity. Since Lugol's solution, used in this work for fixing the phytoplankton before counting, disrupts colonies, information about increase in colony size could not be obtained. It can be hypothesized, however, that the enhanced carbohydrate synthesis observed in the early phases of development of the Phaeocystis sp. bloom would provide not only catabolic energy for further cell division, but also for increasing the buoyancy of new colonies formed near the bottom of the water column, so that they move upwards to the higher light levels suitable for active growth.

The photosynthetic carbon metabolism of Phaeocystis sp. during the declining phase of the bloom, which took place in the 3L4 microcosms and in Expt 4
(Groups V and VI), displayed the main characteristics of slowed growth. Protein-SSR decreased, as compared to the early stages of development, reaching values lower than $0.05 \mathrm{~d}^{-1}$. The relative incorporation of ${ }^{14} \mathrm{C}$ into LMWM and the carbon present in ASC also decreased during this period, while at the same time, the relative incorporation into lipids and the concentration of carbon in this pool showed important increases (Table 3, Figs, $4 \& 5$ ). This pattern is consistent with a reduction in the flow of carbon into the colonial matrix and with an increase in the accumulation of cellular storage products. Phaeocystis sp. colonies disrupt, releasing motile cells, as a consequence of nutrient depletion (Verity et al. 1988). This would explain the lower flux of carbon into LMWM and the decrease in ASC-C at the end of the bloom (Table 3, Figs, 4 \& 5).

Davies et al. (1992) suggested that an active downward migration of single cells released by ageing colonies during the later stages of the bloom completes the life cycle of Phaeocystis sp. Enhanced ${ }^{14} \mathrm{C}$ incorporation and accumulation of lipids observed in nutrientdepleted Phaeocystis sp. populations are in accord with this hypothesis (Table 3, Figs. 4 \& 5). Although there is a lack of information for Phaeocystis sp., lipid storage in overwintering benthic forms has been reported for other phytoplankton groups (e.g. Berkaloff \& Kader 1975, Amblard \& Bourdier 1990).

\section{Metabolic succession}

Changes in the pathways of carbon flow within the cells and in the biochemical composition of the populations observed throughout the seasonal diatom-Phaeocystis sp. succession have certain trophic implications.

The proportions of carbon incorporation into proteins and the fraction of carbon present in this pool increased slowly from the beginning of the study up to the diatom bloom (Group III), then decreased sharply in the diatom - Phaeocystis sp. transition (Fig. 8). However, although the highest polysaccharide SSR were also measured for Group III, the relative contribution of polysaccharide-C to total carbon displayed a slow but continuous increase during the succession. The ultimate consequence of these metabolic trends was a decrease in the protein/ASC ratio as succession progressed (Fig. 3). Evidence is beginning to accumulate suggesting that grazing by herbivorous zooplankton is a selective process dependent on the nutritional. quality of the food supply (Libourel-Houde \& Roman 1987), tending to maximize nitrogenous ingestion (Cowles et al. 1988). Besides the effect of cell size and morphology, the decrease in the protein/polysaccharide ratio observed in this study is expected to 
lead to reduced ingestion rates and density of grazers. This was observed during the parallel field survey (Davies et al. 1992).

A continuous increase in the proportion of $\mathrm{C}$ incorporated into LMWM and a parallel increase in the contribution of ASC-C to total carbon was also observed during the succession. This physiological pattern, which relates to the formation of the mucilaginous envelope by Phaeocystis sp. (see discussion above), eventually leads to higher rates of extracellular release of organic carbon (Guillard \& Hellebust 1971, Lancelot 1983). The organic carbon released by this organism has been suggested to serve as an energy source for the growth of microheterotrophs (Veldhuis et al. 1986). This fact is consistent with the increase in bacterial biomass and activity observed after blooms of this species (Billen \& Fontigny 1987).

Thus, the succession of well-differentiated metabolic behaviours during winter-spring, from an active protein metabolism during a diatom bloom to carbohydrate-dominated metabolism in Phaeocystis sp. outbursts, would inevitably influence the trophic structure of the planktonic ecosystem from the classical food chain at the early stages, and mainly during the diatom bloom, to a dominance of the microbial loop at the end of the Phaeocystis sp. bloom.

Acknowledgements. We acknowledge support from the Ministry of Agriculture, Fisheries and Food under contract GCB 10. This work forms part of Laboratory Research Project 2 of the Plymouth Marine Laboratory, a component of the Natural Environmental Research Council. We thank Dr Ian R Joint for comments on the manuscript. E.F. acknowledges the receipt of a post-dostoral fellowship from F.I.C.Y.T of the Principado de Asturias. I. de M. was funded by a sectoral grant from the Commission of the European Community.

\section{LITERATURE CITED}

Amblard, C., Bourdier, G. (1990). The spring bloom of the diatom Melosira italica subsp. subartica in Lake Pavin: biochemical, energetic and metabolic aspects during sedimentation. J. Plankton Res. 12(3): 645-660

Barlow, R. G. (1982). Phytoplankton ecology in the southern Benguela current. II. Carbon assimilation patterns. J. exp. mar. Biol. Ecol, 63: 229-237

Barlow, R. G. (1984). Dynamics of the decline of a phytoplankton bloom after an upwelling event. Mar. Ecol. Prog. Ser. 16: 121-126

Barnes, H., Blackstock, J. (1973). Estimation of lipids in marine animals and tissues; detailed investigation of the sulphophosphovanillin method for 'total' lipids. J exp. mar. Biol. Ecol. 12: 103-118

Berkaloff, C., Kader, J. C. (1975). Variations of the lipid composition during the formation of cysts in the green alga Protosiphon botryoides. Phytochemistry 14: 2353-2355

Billen, G., Fontigny, A. (1987). Dynamics of a Phaeocystisdominated spring bloom in Belgian coastal waters. II. Bacterioplankton dynamics. Mar. Ecol. Prog. Ser. 37: 249-257
Clayton, J. R., Dortch, Q., Thoresen, S. S., Ahmed, S. I. (1988). Evaluation of methods for separation and analysis of proteins and free aminoacids in phytoplankton samples. J. Plankton Res. 10: 341-358

Cowles, T J., Olson, R. J., Chisholm, S. W. (1988). Food selection by copepods: discrimination on the basis of food quality. Mar. Biol. 100: 41-49

Davies, A. G., Madariaga, I. de, Bautista, B., Fernández, E. Harbour, D. S., Serret, P., Tranter, P. R. G. (1992). The ecology of a coastal Phaeocystis bloom in the north-western English Channel in 1990. J. mar. biol. Ass. U.K. 72:691-708

Dortch, Q., Packard, T T (1989). Differences in biomass structure between oligotrophic and eutrophic marine ecosystems. Deep Sea Res. 36(2): 223-240

Dubois, M., Gilles, K. A., Hamilton, J. K., Rebers, P. A., Smith, F. (1956). Colorimetric method for determination of sugar and related substances. Analyt. Chem. 28: 350-356

Guillard, R. R. L., Hellebust, J. A. (1971). Growth and the production of extracellular substances by two strains of Phaeocystis pouchetii. J. Phycol. 7: 330-338

Hama, I., Handa, N., Takahashi, M., Whitney, F., Wong, C. S (1988a). Change in distribution patterns of photosynthetically incorporated $\mathrm{C}$ during phytoplankton bloom in controlled experimental ecosystem. J. exp. Mar. Biol. Ecol. 120: $39-56$

Hama, T., Honjo, T (1987). Photosynthetic products and nutrient availability in phytoplankton population from Gokasho Bay, Japan. J. exp. mar. Biol. Ecol. 112: 251-266

Hama, T., Matsunaga, K., Handa, N., Takahashi, M. (1988b). Day-night changes in production of carbohydrates and protein by natural phytoplankton population from Lake Biwa, Japan. J. Plankton Res. 12: 133-147

Harding, L. W. Jr, Meeson, B. W., Fisher, T. R. (1985). Patterns of photosynthetic carbon metabolism in light-limited phytoplankton. Mar. Biol. 89: 121-133

Haug, A., Myklestad, S., Sakshaug, E. (1973). Studies on the phytoplankton ecology of the Trondheimsfjord. I. The chemical composition of phytoplankton populations. J. exp. mar. Biol. Ecol. 11: 15-26

Hitchcock, G. L. (1978). Labelling patterns of carbon-14 in net plankton during a winter-spring bloom. J. exp. mar. Biol. Ecol. 31. 141-153

Holligan, P. M., Harris, R. P., Newell, R. C., Harbour, D. S., Head, R. N., Linley, E. A. S., Lucas, M. I., Tranter, P. R. G., Weekley, C. M. (1984). Vertical distribution and partitioning of inorganic carbon in mixed, frontal and stratified waters of the English Channel. Mar. Ecol. Prog. Ser. 14: $111-127$

Jukes, T. H., Holmquist, R., Moise, H. (1975). Aminoacid composition of proteins: selection against the genetic code. Science 189: 50-51

Konopka, A. (1983). The effect of nutrient limitation and its interaction with light upon the products of photosynthesis in Merismopedia tenuissima (Cyanophyceae). J. Phycol. 19: $430-409$

Lancelot, C. (1983). Factors affecting phytoplankton extracellular release in the Southern Bight of the North Sea. Mar. Ecol. Prog. Ser. 12: 115-121

Lancelot, C., Mathot, S. (1985). Biochemical fractionation of primary production by phytoplankton in Belgian coastal waters during short- and long-term incubation with ${ }^{14} \mathrm{C}$ bicarbonate. I. Mixed diatom population. Mar. Biol. 86: 219-226

Lancelot, C., Mathot, S. (1987). Dynamics of a Phaeocystisdominated spring bloom in Belgian coastal waters. I. Phytoplanktonic activities and related parameters. Mar. Ecol. Prog. Ser. 37: 239-248 
Lancelot, C., Mathol, S., Owens, N. P. J. (1986). Modelling protein synthesis, a step to an accurate estimate of net primary production: Phaeocystıs pouchetii colonies in Belgian coastal waters. Mar. Ecol. Prog. Ser. 32: $193-202$

Lean, D. R. S., Cuhel, R. L., Charlton, M. N. (1989). Protein synthesis: a measure of growth for lake plankton. Hydrobiologia 173: 119-126

Li, W. K. W., Glover, H. E., Morris, I. (1980). Physiology of carbon photoassimilation by Oscillatoria thiebautii in the Caribbean Sea. Limnol. Oceanogr. 25: 447-456

Libourel-Houde, S. E., Roman, M. R. (1987). Effects of food quality on the functional ingestion response of the copepod Acartia tonsa. Mar. Ecol. Prog. Ser. 40: 69-77

Lowry, M., Rosenbrough, J., Fara, A. L., Randall, J. R. (1951). Protein measurement with the Folin phenol reagent. J. biol. Chem. 193: 265-275

Madariaga, I. de (1992). Interspecific differences in photosynthetic carbon metabolism of marine phytoplankton. Mar. Biol. (in press)

Madariaga, I. de, Fernández, E. (1990). Photosynthetic carbon metabolism of size-fractionated phytoplankton during an experimental bloom in marine microcosms. J. mar. biol. Ass. U.K. 70: $531-543$

Madariaga, I. de, Fermández, E., Serret, P. (1991). Testing the validity of the synthesis ratio of protein to low molecular weight metabolites as an estimation of phytoplankton growth in the field. J. mar. biol. Ass. U.K. $71: 48-492$

McConville, M. J., Mitchell, C., Wetherbee, R. (1985). Patterns of carbon assimilation in a microalgal community from annual sea ice, East Antarctica. Polar Biol. 4: 135-141

Morris, I. (1981). Photosynthetic products, physiological state, and phytoplankton growth. Can. Bull. Fish. Aquat. Sci. 210: $83-102$

Morris, I., Glover, H. E., Yentsch, C. S. (1974). Products of photosynthesis by marine phytoplankton: the effect of environmental factors on the relative rates of protein synthesis. Mar. Biol. 27: 1-9

Morris, R. J., McCartney, M. J., Robinson, G. A. (1983). Studies of a spring phytoplankton bloom in an enclosed

This article was submitted to the editor experimental ecosystem. 1. Biochemical changes in relation to the nutrient chemistry of water $\mathrm{J}$. exp. mar. Biol. Ecol. 70: 249-262

Myklestad, S. (1977). Production of carbohydrates by marine planktonic diatoms. II. Influence of the N/P ratio in the growth medium on the assimilation ratio, growth rate, and production of cellular and extracellular carbohydrates by Chaetoceros affinis var. willei (Gran) Hustedt and Skeletonema costatum (Grev.) Cleve. J. exp. mar. Biol. Ecol. 29: 161-179

Myklestad, S. (1978). $\beta-1,3$-glucans in diatoms and brown seaweeds. In: Hellebust, J A., Craigie, J. S. (eds.) Handbook of phycological methods. Cambridge University Press, Cambridge, p. 133-142

Rivkin, R. B. (1985). Carbon-14 labelling patterns of individual phytoplankton from natural populations. Mar. Biol. 89: $135-142$

Rivkin, R. B. (1989). Influence of irradiance and spectral quality on the carbon metabolism of phytoplankton. I. Photosynthesis, chemical composition and growth. Mar. Ecol. Prog. Ser. 55: 291-304

SAS Institute (1985). SAS procedures guide for personal computers. Version 6 edin. SAS Institute, inc, Cary, NC

Skreslet, S. (1988). Buoyancy in Phaeocystis pouchetii (Hariot) Lagerheim. J. exp. mar. Biol. Ecol. 119: 157-166

Strickland, J D. H., Parsons, T R. (1972). A practical handbook of seawater analysis, 2nd edn. Fisheries Research Board of Canada, Ottawa

Sverdrup, H. V. (1953). On conditions for the vernal blooming of phytoplankton. J. Cons, perm. int. Explor. Mer 18: 287-295

Veldhuis, M. J. W., Admiraal, W., Colijn, F. (1986). Chemical and physiological changes of phytoplankton during the spring bloom dominated by Phaeocystis pouchetil (Haptophyceae): observations in Dutch coastal waters of the North Sea. Neth. J. Sea Res. 20: 49-60

Verity, P. G., Villareal, T A., Smayda, T. J (1988). Ecological investigations of blooms of colonial Phaeocystis pouchetii. I. Abundance, biochemical composition, and metabolic rates. J. Plankton Res. 10: 219-24

Manuscript first received: May 15, 1992

Revised version accepted: October 21, 1992 